\title{
Evidence and quantitation of aromatic organosulfates in ambient aerosols in Lahore, Pakistan
}

\author{
S. Kundu ${ }^{1}$, T. A. Quraishi ${ }^{*}$, G. Yu ${ }^{2}$, C. Suarez ${ }^{2}$, F. N. Keutsch ${ }^{2}$, and E. A. Stone ${ }^{1}$ \\ ${ }^{1}$ Department of Chemistry, University of Iowa, Iowa City, IA 52242, USA \\ ${ }^{2}$ Department of Chemistry, University of Wisconsin-Madison, Madison, Wisconsin 53706, USA \\ * formerly at: Institute of Environmental Engineering and Research, University of Engineering \\ and Technology, Lahore, Pakistan
}

Correspondence to: E. A. Stone (betsy-stone@uiowa.edu)

Received: 20 November 2012 - Published in Atmos. Chem. Phys. Discuss.: 19 December 2012

Revised: 29 March 2013 - Accepted: 5 April 2013 - Published: 14 May 2013

\begin{abstract}
Organosulfates are important components of atmospheric organic aerosols, yet their structures, abundances, sources and formation processes are not adequately understood. This study presents the identification and quantitation of benzyl sulfate in atmospheric aerosols, which is the first confirmed atmospheric organosulfate with aromatic carbon backbone. Benzyl sulfate was identified and quantified in fine particulate matter $\left(\mathrm{PM}_{2.5}\right)$ collected in Lahore, Pakistan, during 2007-2008. An authentic standard of benzyl sulfate was synthesized, standardized, and identified in atmospheric aerosols with quadrupole time-of-flight (Q-ToF) mass spectrometry (MS). Benzyl sulfate was quantified in aerosol samples using ultra performance liquid chromatography (UPLC) coupled to negative electrospray ionization triple quadrupole (TQ) MS. The highest benzyl sulfate concentrations were recorded in November and January 2007 $\left(0.50 \pm 0.11 \mathrm{ng} \mathrm{m}^{-3}\right)$ whereas the lowest concentration was observed in July $\left(0.05 \pm 0.02 \mathrm{ng} \mathrm{m}^{-3}\right)$. To evaluate matrix effects, benzyl sulfate concentrations were determined using external calibration and the method of standard addition; comparable concentrations were detected by the two methods, which ruled out significant matrix effects in benzyl sulfate quantitation. Three additional organosulfates with $m / z, 187,201$ and 215 were qualitatively identified as aromatic organosulfates with additional methyl substituents by high-resolution mass measurements and tandem MS. The observed aromatic organosulfates form a homologous series analogous to toluene, xylene, and trimethylbenzene, which are abundant anthropogenic volatile organic compounds (VOC), suggesting that aromatic organosulfates may
\end{abstract}

be formed by secondary reactions. However, stronger statistical correlations of benzyl sulfate with combustion tracers (EC and levoglucosan) than with secondary tracers $\left(\mathrm{SO}_{4}^{2-}\right.$ and $\alpha$-pinene-derived nitrooxy organosulfates) suggest that aromatic organosulfates may be emitted from the combustion sources or their subsequent atmospheric processing. Further studies are needed to elucidate the sources and formation pathways of aromatic organosulfates in the atmosphere.

\section{Introduction}

Atmospheric aerosols absorb and scatter solar radiation (direct aerosol effect) (Mccormic and Ludwig, 1967; Ramanathan et al., 2001) and can act as cloud condensation nuclei (CCN) (indirect aerosol effect) (Twomey, 1974; Roberts et al., 2003), thereby altering the earth's radiative balance. Aerosols also exert indirect effects on climate by changing biogeochemical cycles (Mahowald, 2011). Epidemiological and toxicological studies have demonstrated that aerosols cause inflammation and other negative health effects on respiratory and cardiovascular systems, increasing morbidity and mortality (Davidson et al., 2005; Pope et al., 2002). The health and climate effects of aerosols depend, in part, on their chemical composition.

Organic matter is a significant component of ambient aerosol mass, but remains the most poorly characterized fraction due to its chemical complexity and multitude of sources. Submicron aerosols are largely comprised of organic matter, comprising 20-90\% of particle mass (Hallquist et al., 
2009; Kanakidou et al., 2005). Much of the aerosol organic matter, particularly the water-soluble fraction, is not chemically speciated at the molecular level (Hallquist et al., 2009; Goldstein and Galbally, 2007; Saxena and Hildemann, 1996). The lack of understanding organic aerosol on a molecular level limits the understanding of the sources, formation, chemical evolution, and nucleation of organic aerosols (Fuzzi et al., 2006; Kundu et al., 2010; Riipinen et al., 2012). Molecular level organic composition is also important to understand their optical and CCN properties and health effects (Hallquist et al., 2009; Shapiro et al., 2009; Ervens et al., 2005).

Organosulfates are a component of aerosol organic matter whose sources, precursors, composition, and formation processes are beginning to be explored. These molecules, which contain a distinctive sulfate functional group, have been identified in atmospheric aerosols, rain, fog water, and chamber-generated SOA (Iinuma et al., 2007; Surratt et al., 2008; Altieri et al., 2009; Mazzoleni et al., 2010; SchmittKopplin et al., 2010; Stone et al., 2012). Very few organosulfate species have been identified and quantified in atmospheric aerosols due to the lack of quantification standards. Standards have been synthesized for glycolic acid sulfate and lactic acid sulfate; their application to field studies have shown that these compounds are ubiquitous in urban and rural locations but account for only a small fraction (less than $0.2 \%$ ) of organic aerosol (Olson et al., 2011). The development of atmospherically-relevant organosulfate standards would greatly improve the understanding of their chemical composition and atmospheric abundance (Olson et al., 2011; Iinuma et al., 2007) and provide a means to further study their chemical and physical properties and atmospheric sources.

Estimates of total organosulfate contributions to aerosol mass are highly dependent on measurement methods. FTIR spectroscopy, measuring organosulfate light absorption at $876 \mathrm{~cm}^{-1}$ after the elimination of sulfate and carbonate interferences, indicates that organosulfates account, on average, for $3.8-5.1 \%$ of organic matter and $2.2-3.6 \%$ of inorganic sulfate in aerosols (Hawkins et al., 2010). A semiquantitative approach using liquid chromatography coupled with mass spectrometry applied to aerosol in Asia estimated that organosulfates on average accounted for $2.3 \%$ of organic carbon and $3.8 \%$ of total sulfate (Stone et al., 2012). Sulfur analyses (elemental sulfur, sulfate, and methane sulfonate) have suggested that organosulfates can account for as much as $5-30 \%$ of organic matter in ambient aerosols (Surratt et al., 2008; Tolocka and Turpin, 2012) and 6-14\% of sulfate concentrations (Lukács et al., 2009).

Biogenic VOC are established precursors for organosulfates in the atmosphere. Isoprene, $\alpha$-pinene, $\beta$-pinene, $\beta$-caryophyllene, and their oxidation products have been demonstrated to form organosulfates in the laboratory (Iinuma et al., 2007; Chan et al., 2011; Surratt et al., 2008; Perri et al., 2010). A number of biogenic organosulfates have also been observed in ambient atmospheres, with isoprene derived organosulfates among the most prevalent (Hatch et al., 2011; Froyd et al., 2010; Stone et al., 2012). Smog chamber and cloud processing experiments have demonstrated enhanced organosulfate production under acidic conditions (Surratt et al., 2008; Perri et al., 2010) and upon evaporation and re-dissolution, suggesting that their formation may be mediated by aqueous phase processes (Nguyen et al., 2012).

Much remains to be explored in terms of the molecular diversity of organosulfates in the atmosphere. In a preceding study of organosulfates in Asia, an organosulfate with chemical formula $\mathrm{C}_{7} \mathrm{H}_{7} \mathrm{SO}_{4}^{-}$was observed with highresolution mass spectrometry and suggested to be an aromatic organosulfate with a toluene backbone (Stone et al., 2012). Of the several fine particulate matter $\left(\mathrm{PM}_{2.5}\right)$ samples studied in this survey of Asian aerosol, this organosulfate was detected only in the megacity of Lahore, Pakistan. This heavily industrial location is characterized by high concentrations of $\mathrm{PM}_{2.5}$, with annual average concentrations of $190 \mu \mathrm{g} \mathrm{m}^{-3}$ (Stone et al., 2010). Non-catalyzed motor vehicles are a substantial contribution to $\mathrm{PM}_{2.5}$ organic carbon, averaging 20$51 \mu \mathrm{gC} \mathrm{m}^{-3}$ (Stone et al., 2010). Extremely high concentrations of toxic metals in Lahore (zinc, lead, and cadmium) have been attributed to vehicular and industrial emissions (von Schneidemesser et al., 2010).

In this study, the presence of aromatic organosulfates in Lahore is confirmed with an authentic standard and the abundance of benzyl sulfate $\left(\mathrm{C}_{7} \mathrm{H}_{7} \mathrm{SO}_{4}^{-}\right)$was determined with UPLC coupled with high-resolution and tandem MS. The temporal variation in benzyl sulfate concentrations is discussed in the context of other aerosol components and synoptic meteorology. The role of the aerosol matrix in the quantification of benzyl sulfate was examined by applying both external calibration and the method of standard addition. Finally, three other aromatic organosulfates are qualitatively identified, forming a homologous series of aromatic organosulfates with increasing methyl substituents. The potential sources and formation processes of these unique compounds in the atmosphere are discussed.

\section{Experimental section}

\subsection{Aerosol collection}

Fine particulate matter $\left(\mathrm{PM}_{2.5}\right)$ samples were collected on the campus of the University of Engineering and Technology in Lahore, Pakistan, as described in a previous publication (Stone et al., 2010). Briefly, an eight-channel mediumvolume $\mathrm{PM}_{2.5}$ and $\mathrm{PM}_{10}$ sampler (URG-3000ABC, Chapel Hill, NC, USA) was placed on the rooftop of the Institute for Environmental Engineering and Research at the height of $10 \mathrm{~m}\left(31^{\circ} 15^{\prime}, 31^{\circ} 45^{\prime} \mathrm{N}\right.$ and $\left.74^{\circ} 10^{\prime}, 74^{\circ} 39^{\prime} \mathrm{E}\right)$. $\mathrm{PM}_{2.5}$ was selected by a Teflon-coated aluminum cyclone operating at an approximate flow rate of 16 liters per minute. Filter samples were collected on pre-baked quartz-fiber substrates $(47 \mathrm{~mm}$, 
Pall Life Sciences, East Hill, NY, USA) for the duration of $24 \mathrm{~h}$, with sample collection beginning at 11:00 LT. Samples were collected from 12 January 2007 to 13 January 2008 at a rate of one-in-six days, yielding 63 samples. One field blank was collected for every five aerosol samples following procedures analogous to those used for sample collection, except no air was passed through the filter. Only the $\mathrm{PM}_{2.5}$ samples were analyzed in this study.

\subsection{Synthesis of benzyl sulfate standard}

A standard of benzyl sulfate $\left(\mathrm{C}_{7} \mathrm{H}_{7} \mathrm{SO}_{4}^{-}\right)$was synthesized following a previously reported protocol (Olson et al., 2011; Galloway et al., 2009). Briefly, $1 \mathrm{~mL}$ benzyl alcohol ( $\geq 99.0 \%$, Sigma-Aldrich) and $2 \mathrm{~mL}$ diisopropylethyl amine (DIEA, $99.5 \%$ Anaspec, Inc.) were dissolved in $50 \mathrm{~mL}$ acetonitrile (anhydrous, 99.8\% Sigma-Aldrich). The solution was cooled to $0{ }^{\circ} \mathrm{C}$ and $0.8 \mathrm{~mL}$ chlorosulfonic acid $(99 \%$ Sigma-Aldrich) was added dropwise over $15 \mathrm{~min}$. The solution was stirred and allowed to react in an ice bath for three hours. Acetonitrile was removed by rotary evaporation. The resulting product was used without further purification. The mass fraction of benzyl sulfate was determined by proton nuclear magnetic resonance $\left({ }^{1} \mathrm{H} \mathrm{NMR}\right)$, as described previously (Olson et al., 2011). A $0.1354 \mathrm{~g}$ portion of the product mixture was dissolved in $1.0 \mathrm{~mL} \mathrm{D}_{2} \mathrm{O}$ with $10.0 \mu \mathrm{L}$ dichloroacetic acid (DCA) as an internal standard. An NMR spectrum was taken by a $300 \mathrm{MHz}$ Varian NMR spectrometer with 16 scans, $75 \mathrm{~s}$ relaxation delay time, and $45^{\circ}$ pulse flip angle.

\subsection{Aerosol extraction method}

$\mathrm{PM}_{2.5}$ samples from Lahore, Pakistan, were composited according to a prior study (Stone et al., 2010). Subsamples of each filter were obtained using a standardized filter punch $\left(1.0 \mathrm{~cm}^{2}\right)$ and were combined by month. Composite samples were extracted into $10.0 \mathrm{~mL}$ methanol (Optima ${ }^{\circledR L C} / \mathrm{MS}$ grade, Fisher Scientific) by ultrasonication for $40 \mathrm{~min}$ (Stone et al., 2012). Although methanol has been shown to esterify carboxylic acid moieties in organosulfate molecules (O1son et al., 2011) this reaction does not impact the analytes in this study. Extracts were filtered through a PTFE syringe filter $(0.2 \mu \mathrm{m}$ pore size $)$ and then dried under ultra high purity nitrogen gas (5 psi) at $50{ }^{\circ} \mathrm{C}$ to promote the evaporation of solvent, using a nitrogen evaporation system (TurboVap®LV, Caliper Life Sciences). The sample residue was then reconstituted in $500 \mu \mathrm{L}$ of water and methanol $(2: 1)$. The reconstituted sample was stored in the refrigerator overnight prior to chemical analysis. Quality control samples were prepared analogously, and included 3 laboratory blanks, 3 field blanks, and 6 spike recovery samples ( 3 at each $5.0 \mathrm{ppb}\left[\mathrm{ng} \mathrm{mL}^{-1}\right.$ ] and $25.0 \mathrm{ppb}$ ). Benzyl sulfate and other aromatic organosulfates were not detected in the field blanks, confirming that benzyl sulfate was not introduced by filter media, handling, transport, or storage. To evaluate potential extraction artifacts, $0.1 \mathrm{nmol}$ of benzyl alcohol and $100 \mathrm{nmol}$ of $\mathrm{H}_{2} \mathrm{SO}_{4}$ were spiked on a quartz fiber filter and extracted and analyzed like aerosol samples. Benzyl sulfate was not detected in this sample, suggesting that benzyl sulfate was not formed during aerosol extraction, which is consistent with a prior study that showed that the reaction between alcohol and $\mathrm{H}_{2} \mathrm{SO}_{4}$ is not feasible even under most acidic conditions observed in the atmosphere (Minerath et al., 2008).

\subsection{Chemical analysis}

Aerosol extracts were analyzed by ultra performance liquid chromatography (UPLC, Waters ACQUITY). The separation of analytes were achieved on a high strength silica (HSS) reversed phase C18 column (ACQUITY UPLC®HSS T3, $2.1 \mathrm{~mm}$ ID $\times 75 \mathrm{~mm}$ length, $1.8 \mu \mathrm{m}$ particle size) at $45^{\circ} \mathrm{C}$ using aqueous and organic mobile phases. The mobile phase conditions have been adapted from the literature (Surratt et al., 2008). The aqueous mobile phase consisted of $0.1 \%$ acetic acid (glacial, $>99 \%$ VWR) in high-purity water (resistivity $>18.2 \mathrm{M} \Omega-\mathrm{cm}$ ) and the organic mobile phase consisted of $0.1 \%$ acetic acid in methanol (Optima ${ }^{\circledR L C} / \mathrm{MS}$ grade, Fisher Scientific). The organic mobile phase was maintained at $0 \%$ for the first $2 \mathrm{~min}$. It was increased to $90 \%$ from 2 to $10 \mathrm{~min}$, held at $90 \%$ from 10 to $10.2 \mathrm{~min}$, and then decreased back to $0 \%$ from 10.2 to 12 min for reequilibration. The eluent flow rate was $0.3 \mathrm{~mL} \mathrm{~min}{ }^{-1}$.

Triple quadrupole mass spectrometry (TQ MS, Waters ACQUITY) was used for the quantitation of benzyl sulfate. The instrument was equipped with an electrospray ionization (ESI) source operating in the negative mode. The applied ESI conditions were capillary voltage $2.6 \mathrm{kV}$, sample cone voltage $38 \mathrm{~V}$, desolvation temperature $350^{\circ} \mathrm{C}$, source temperature $150{ }^{\circ} \mathrm{C}$, cone gas flow rate $25 \mathrm{~L} \mathrm{~h}^{-1}$, desolvation gas flow rate $600 \mathrm{~L} \mathrm{~h}^{-1}$ and collision gas flow rate $0.1 \mathrm{~mL} \mathrm{Min}^{-1}$. The injection volume was $5.0 \mu \mathrm{L}$. Data were acquired by multiple reaction monitoring (MRM) mode; the molecular ion of benzyl sulfate $(\mathrm{m} / \mathrm{z}, 187)$ was selected in the first quadruple, followed by fragmentation in the second quadrupole and detection of product ions in the third quadruple. MS conditions were pre-optimized for fragments $\mathrm{m} / \mathrm{z} 77\left(\mathrm{C}_{6} \mathrm{H}_{5}^{-}\right)$, 81( $\left.\mathrm{HSO}_{3}^{-}\right), 96\left(\mathrm{SO}_{4}^{-}\right)$, and $107\left(\mathrm{C}_{7} \mathrm{H}_{7} \mathrm{O}^{-}\right)$, with optimized collision energies of $28,24,24$, and $28 \mathrm{~V}$, respectively. The product ion at $\mathrm{m} / \mathrm{z} 96$ was used for quantitation purposes because its signal-to-noise ratio was $4-6$ times higher than other product ions. All data were acquired and processed using MassLynx software (version 4.1).

The UPLC/TQ MS was calibrated daily with a nine-point calibration curve of benzyl sulfate. Linear response was observed over concentrations ranging from 0.1 to $300 \mathrm{ppb}$, and a narrower range from $0.1-150 \mathrm{ppb}$ of benzyl sulfate standard was applied to aerosol samples. The limit of quantitation (LOQ) was determined based on the multiple injections $(n=10)$ of $0.1 \mathrm{ppb}$ of benzyl sulfate standard. 
For standard addition experiments, six point standard addition curves were developed for each ambient aerosol sample by adding known amounts of benzyl sulfate to increase its response by a factor of $1: 4$. Concentrations of added benzyl sulfate standard were plotted as abscissa and peak responses were plotted as ordinate in the standard addition calibration curve. Relations with $r^{2}=0.93-0.99$ were obtained in leastsquares linear regression analyses. Following the method of standard addition, the concentration of benzyl sulfate in the original extract was calculated from the $\mathrm{x}$-intercept and corrected for dilution, which occurred when adding standard.

Uncertainty in the measurement of benzyl sulfate was expected to arise from (1) the error in slope and intercept of external/standard addition calibration curve $\left(\mathrm{e}_{\mathrm{Cal}}\right),(2)$ recovery of benzyl sulfate from the extraction $\left(\mathrm{e}_{\mathrm{Re}}\right)$, (3) nearness to detection limit $\left(\mathrm{e}_{\mathrm{Dl}}\right)$, and (4) reproducibility of the aerosol extraction ( $\left.\mathrm{e}_{\text {Dup }}\right)$. The combined relative uncertainty $\left(\% \mathrm{e}_{\text {Total }}\right)$ was propagated using the following equation:

$\% \mathrm{e}_{\mathrm{Total}}=\sqrt{\% \mathrm{e}_{\mathrm{Cal}}^{2}+\% \mathrm{e}_{\mathrm{Re}}^{2}+\% \mathrm{e}_{\mathrm{Dl}}^{2}+\% \mathrm{e}_{\mathrm{Dup}}^{2}}$

Qualitative identification of benzyl sulfate and other aromatic organosulfates utilized quadruple time-of-flight mass spectrometry (Q-ToF MS, Micromass MS technologies). The ESI source was operated in the negative mode with capillary voltage $2.6 \mathrm{kV}$, sample cone voltage $40 \mathrm{~V}$, desolvation temperature $350^{\circ} \mathrm{C}$, source temperature $100^{\circ} \mathrm{C}$, cone gas flow rate $25 \mathrm{~L} \mathrm{~h}^{-1}$, desolvation gas flow rate $350 \mathrm{~L} \mathrm{~h}^{-1}$ and collision gas flow rate $0.25 \mathrm{~mL} \mathrm{~min}^{-1}$. Data were collected from $\mathrm{m} / \mathrm{z}$ 40 to 400 with $\mathrm{V}$ geometry in reflectron mode. A small peptide, Val-Tyr-Val (Sigma-Aldrich) with $\mathrm{m} / \mathrm{z} 378.2029$ was used for lock mass correction to obtain high-resolution MS data. Tandem mass spectrometry was performed by Q-ToF on precursor ions with $\mathrm{m} / \mathrm{z}, 187,201$ and 215. For tandem mass fragmentation, a $15 \mathrm{~V}$ collision energy and previously described ESI conditions were applied. Resulting data were processed by background and noise subtraction. The background was defined as signal with intensity less than 75 counts per second (cps) and was evaluated before and after each chromatographic peak.

\section{Results and discussion}

\subsection{Characterization of benzyl sulfate standard}

The synthesized benzyl sulfate was standardized by ${ }^{1} \mathrm{H}$ NMR. The resulting spectrum of the synthesized product mixture showed the presence of the desired organosulfate $(\delta 5.0 \mathrm{ppm}$ for methylene protons and 7.2-7.4 ppm for aromatic protons), as well as the reactant DIEA $(\delta 1.3,3.1$, and $3.6 \mathrm{ppm}$ ), residual unreacted benzyl alcohol ( $\delta 4.6 \mathrm{ppm}$ for methylene protons and 7.2-7.4 ppm for aromatic protons), acetonitrile $(\delta 2.0 \mathrm{ppm})$, and water $(\delta 4.8 \mathrm{ppm})$ (Fig. S1). The $\delta$ value of methylene proton in benzyl sulfate is higher by 0.4 than that in benzyl alcohol as a result of the replacement of
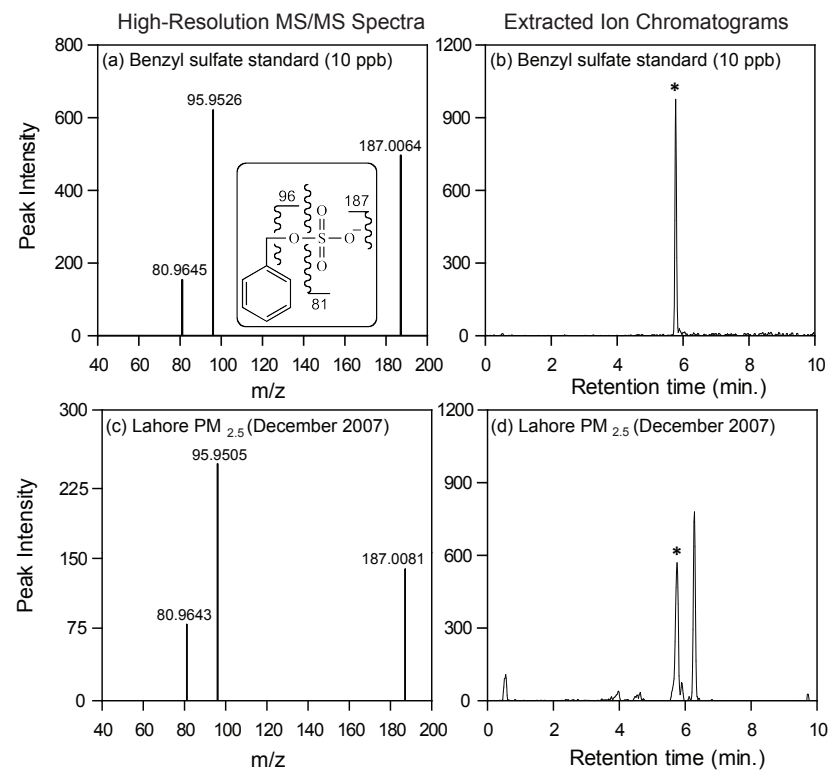

Fig. 1. High resolution product ion mass spectra and extracted ion chromatogram $(\mathrm{m} / \mathrm{z} 187.01 \pm 0.01)$ of benzyl sulfate in a standard $(\mathbf{a}, \mathbf{b})$ and in Lahore, Pakistan, $\mathrm{PM}_{2.5}$ sample collected in December 2007 (c, d). Chromatographic peaks marked with a star correspond to MS/MS spectra.

alcohol functional group by sulfate functional group, similar to the changes in chemical shift observed for glycolic acid and lactic acid (Olson et al., 2011). The integrated area of each peak is proportional to the abundance of ${ }^{1} \mathrm{H}$ in the solution. The benzyl sulfate ${ }^{1} \mathrm{H}$ chemical shift at $5.0 \mathrm{ppm}$ had integrated peak area of 2.85 relative to DCA, whose peak area was set to 1.00 . The analyte and standard molecular weights, relative numbers of protons, peak area ratio, density of DCA, and the molar concentration of DCA indicated that the product mixture contained $23.9 \%$ of benzyl sulfate by mass. The aromatic protons in benzyl sulfate and benzyl alcohol overlapped in the 7.2-7.4 ppm region in the NMR spectrum, and were not used for standardization.

The molecular formula and structure of the benzyl sulfate standard were evaluated by ESI Q-ToF MS to determine its exact mass and product ions. The theoretical $\mathrm{m} / \mathrm{z}$ of the most abundant benzyl sulfate isotopomer is $187.0065 \mathrm{Da}$. In the synthesized standard, the molecular ion was observed at $\mathrm{m} / \mathrm{z}$ of 187.0064 (Fig. 1a), with an error between theoretical and observed masses of $0.5 \mathrm{ppm}$. The major product ions of $\mathrm{m} / \mathrm{z} 187$ are 80.9645 and 95.9526, as shown in Fig. 1a, which were assigned as $\mathrm{HSO}_{3}^{-}$(error $1.2 \mathrm{ppm}$ ) and $\mathrm{SO}_{4}^{-}$(error $9.4 \mathrm{ppm}$ ). The relative errors of the lower mass fragment increase due to the smaller $\mathrm{m} / \mathrm{z}$ values.

Prior studies have documented that organosulfates fragment to a major product ion at $\mathrm{m} / \mathrm{z} 97$, which has been used as a means of identifying parent organosulfates (Stone et al., 2009; Romero and Oehme, 2005). Benzyl sulfate did not fragment to $\mathrm{m} / \mathrm{z}, 97$, and rather had a major product ion 


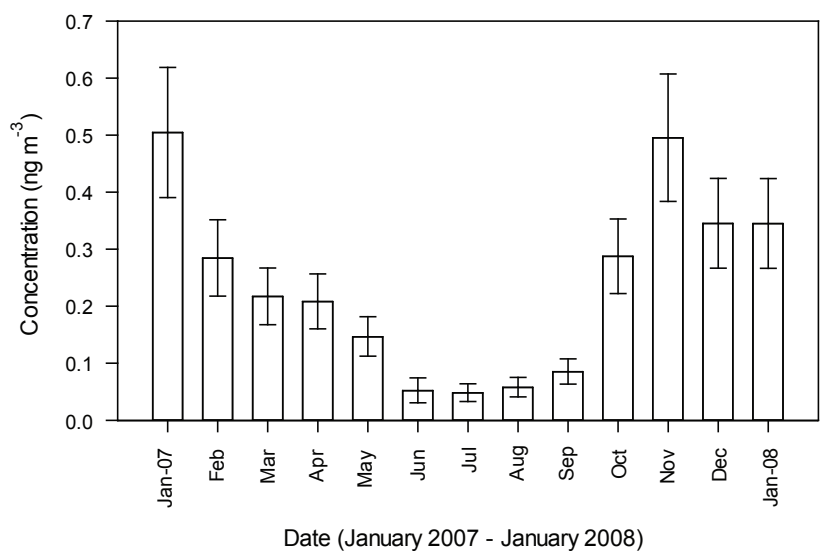

Fig. 2. Monthly average concentrations of benzyl sulfate in $\mathrm{PM}_{2.5}$ in Lahore, Pakistan, determined by UPLC/TQ MS by the method of external calibration. Error bars show the estimate of analytical uncertainty.

at $m / z$ 96, consistent with collisionally-induced dissociation mass spectra of benzyl sulfate (Attygalle et al., 2001). The product ion with $\mathrm{m} / \mathrm{z}, 97$ is formed due to the transfer of a proton from the $\mathrm{C} 2$ position of organosulfates to $\mathrm{SO}_{4}^{2-}$ moiety, as demonstrated by doing the fragmentation analysis of hexadecyl sulfate with deuterium labeling (Attygalle et al., 2001). In benzyl sulfate, there is no hydrogen atom at the $C 2$ position, rendering proton transfer impossible and yielding the major fragment ion of $m / z, 96$, which corresponded to the sulfate radical $\left(\mathrm{SO}_{4}^{--}\right)$.

\subsection{Identification of benzyl sulfate in ambient aerosols}

The presence of benzyl sulfate in aerosol samples was confirmed by parallel analysis of the standard and ambient samples using UPLC Q-ToF MS. Extracted ion chromatograms (EIC) of the benzyl sulfate molecular ion $(m / z, 187.01 \pm 0.01)$ are shown in Fig. 1. The retention time of standard is $5.79 \mathrm{~min}$ (Fig. 1b), which is very near to peak observed at $5.77 \mathrm{~min}$ shown for the December 2007 sample (Fig. 1d). Broadening of the benzyl sulfate peak in the ambient sample is due to the sample solvents and aerosol matrix. The other prominent peak corresponding to $\mathrm{m} / \mathrm{z}$ 187.01 in the aerosol sample is expected to be an isomer of benzyl sulfate and is discussed in Sect. 3.5.

Tandem mass spectral analysis of parent $\mathrm{m} / \mathrm{z} 187$ of the chromatographic peak at $5.77 \mathrm{~min}$ in the aerosol sample yielded $\mathrm{m} / \mathrm{z} 80.9643$ and 95.9505 (Fig. 1c), which were assigned as $\mathrm{HSO}_{3}^{-}$and $\mathrm{SO}_{4}^{--}$(error: 4.2 and $13.0 \mathrm{ppm}$, respectively). As with the benzyl sulfate standard, the $\mathrm{SO}_{4}^{--}$peak is the most dominant product ion followed by $\mathrm{HSO}_{3}^{-}$. Consistency between the benzyl sulfate standard and $\mathrm{PM}_{2.5}$ sample extract, in terms of EIC retention time and tandem mass spectral analysis, confirms the presence of this compound in ambient aerosol.

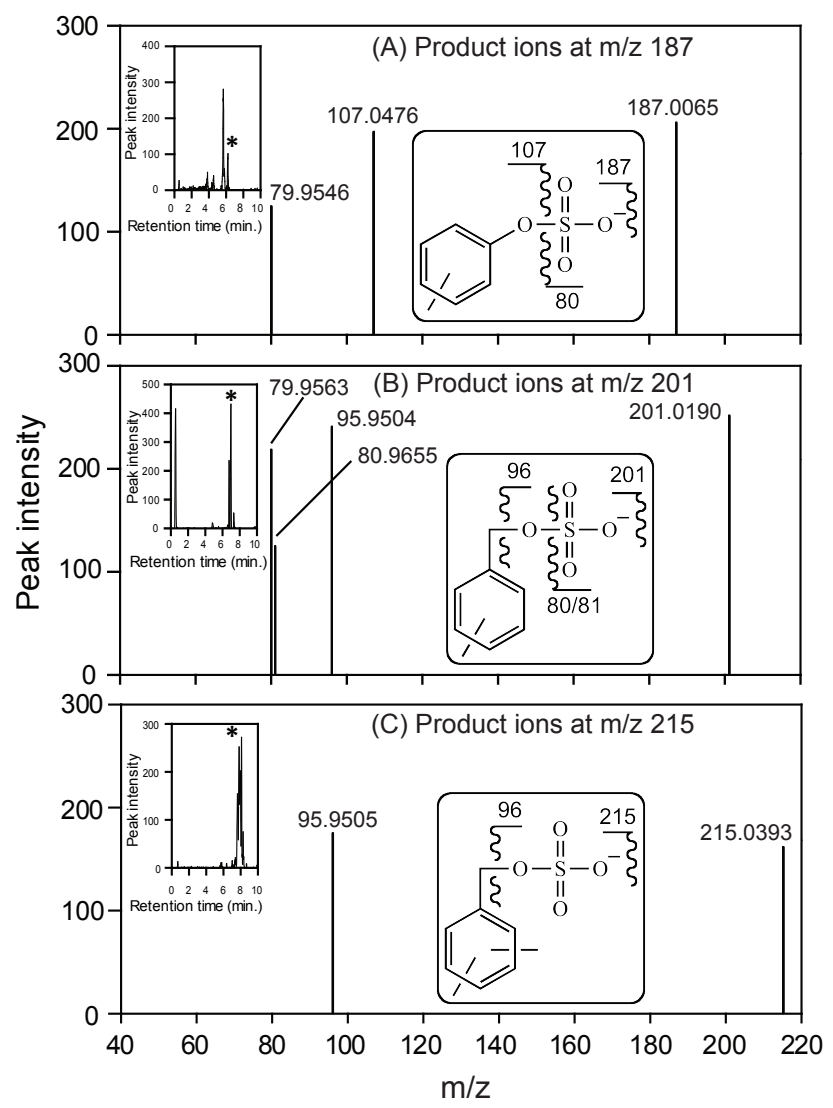

Fig. 3. Tandem mass spectra of aromatic organosulfates with parent $m / z$ of 187 (A), 201 (B) and 215 (C) in $\mathrm{PM}_{2.5}$, Lahore, Pakistan. Chromatographic peaks marked with star were used in generating the product ion mass spectra. Proposed structures are based on molecular formulas and fragment ions.

\subsection{Quantitation of benzyl sulfate}

Benzyl sulfate in atmospheric aerosols was quantified using UPLC TQ MS. For nine-point external calibration curves, least-squares regression demonstrated good linearity $\left(R^{2}\right.$ $>0.995$ ). The LOQ was determined to be $0.16 \mathrm{ppb}$, which is 10 times the standard deviation of peak area of a $0.10 \mathrm{ppb}$ benzyl sulfate standard across 10 injections. The recovery of the spike experiments at $5.0 \mathrm{ppb}$ ranged from 78 to $96 \%$ (av. $86 \%$ ) where the recovery at $25.0 \mathrm{ppb}$ ranged from 75 to $84 \%$ (av. $80 \%$ ). Recovery less than $100 \%$ was expected to be related with minor losses of benzyl sulfate during the aerosol extraction and filtration procedure. Duplicate analyses were carried out for composite aerosol samples from February 2007 and January 2008. The coefficient of variation was $11 \%$ and $14 \%$, respectively. Overall analytical uncertainties were propagated, as described in Sect. 2.4, and ranged from $23-41 \%$ (av. $25 \%$ ).

Ambient concentrations of benzyl sulfate in Lahore, Pakistan, $\mathrm{PM}_{2.5}$ ranged from $0.05-0.50 \mathrm{ng} \mathrm{m}^{-3}$ with average concentration $0.24 \mathrm{ng} \mathrm{m}^{-3}$ (Fig. 2). Two other organosulfate 
species - lactic acid sulfate and glycolic acid sulfate - were measured in a November $2007 \mathrm{PM}_{2.5}$ sample from Lahore at concentrations of $3.8 \mathrm{ng} \mathrm{m}^{-3}$ and $11.3 \mathrm{ng} \mathrm{m}^{-3}$, respectively (Olson et al., 2011). In comparison to these species, benzyl sulfate is an order of magnitude lower in concentration. The contributions of benzyl sulfate to $\mathrm{PM}_{2.5}$ and organic carbon (OC) were found to be small, using data reported in a prior study (Stone et al., 2010). The contribution of benzyl sulfate to $\mathrm{PM}_{2.5}$ mass averaged $1 \times 10^{-4} \%$ and its contribution to OC averaged $2 \times 10^{-4} \%$. Meanwhile, the contribution of total organosulfate was estimated to be $0.7-0.9 \%$ of $\mathrm{PM}_{2.5}$ mass and $0.4-0.8 \%$ of OC in Lahore aerosols (Stone et al., 2012), indicating that benzyl sulfate also makes up a small fraction of organosulfate mass.

\subsection{Temporal variations of benzyl sulfate}

The highest concentrations of benzyl sulfate were observed in November and January $2007\left(0.50 \pm 0.11 \mathrm{ng} \mathrm{m}^{-3}\right)$, whereas lowest concentration was found in July $\left(0.05 \pm 0.02 \mathrm{ng} \mathrm{m}^{-3}\right)$ (Fig. 2). The contribution of benzyl sulfate to organic carbon (OC) was greatest in January 2007 and lowest in July. Wintertime maxima and summertime minima concentrations are consistent with temporal trends observed for $\mathrm{PM}_{2.5}$ mass (Stone et al., 2010). The lowest concentration of benzyl sulfate in summer is related to the wash-out of pollutants by monsoon wind and rain, expanded planetary boundary layer, and lower intensity of pollutant emission (Shafer et al., 2010). Conversely, the wintertime corresponds to the dry season, causing a build-up of pollutants in the atmosphere.

\subsection{Other aromatic organosulfates in atmospheric aerosols}

To qualitatively identify other aromatic organosulfates, a $\mathrm{PM}_{2.5}$ sample from December and a composite $\mathrm{PM}_{2.5}$ sample from January 2007 with high concentrations of benzyl sulfate was subjected to qualitative analysis by UPLC Q-ToF MS, which allowed for molecular formula determination and tandem fragmentations to evaluate organosulfate structure.

As shown in Fig. 3a inset, multiple peaks were observed in the EIC of $\mathrm{m} / z, 187.01 \pm 0.01$. The peak eluting at $5.77 \mathrm{~min}$ and with product ions of $\mathrm{m} / \mathrm{z} 80.9643\left(\mathrm{HSO}_{3}^{-}\right)$and 95.9505 $\left(\mathrm{SO}_{4}^{-}\right)$was confirmed as benzyl sulfate using the authentic standard, as discussed in Sect. 3.2. The other peak eluting at $6.29 \mathrm{~min}$ is an isomer of benzyl sulfate. The mass of a dominant ion under the peak at $6.29 \mathrm{~min}$ is $187.0065 \mathrm{Da}$, which corresponds to $\mathrm{C}_{7} \mathrm{H}_{7} \mathrm{SO}_{4}^{-}$with no detectable error. Tandem mass spectral analyses resulted in product ions at $\mathrm{m} / \mathrm{z} 79.9546$ and 107.0476, which correspond to molecular formulas $\mathrm{SO}_{3}^{-}$(error $34.6 \mathrm{ppm}$ ) and $\mathrm{C}_{7} \mathrm{H}_{7} \mathrm{O}^{-}$(error $19.5 \mathrm{ppm})$, respectively. These product ions are consistent with the structure of an organosulfate with sulfate functional group attached to the aromatic ring, as shown in the Fig. 3a inset. When the sulfate functional group is directly attached to the aromatic ring, the elimination of $\mathrm{SO}_{4}^{--}$is less favorable due to electron delocalization, making $\mathrm{SO}_{3}^{-}$the more abundant sulfur-containing fragment ion (Attygalle et al., 2001). Additionally, it is not possible to transfer $\mathrm{H}^{+}$atom from $\mathrm{C} 2$ position to $\mathrm{SO}_{4}^{2-}$ moiety for the formation of product ion at $\mathrm{m} / \mathrm{z}$ 97. Due to a similar reason, product ion at $\mathrm{m} / \mathrm{z} 97$ was not observed in the fragmentation analysis of benzyl sulfate (Attygalle et al., 2001).

Figure $3 \mathrm{~b}$ shows the EIC of $\mathrm{m} / \mathrm{z}, 201.02 \pm 0.01$ for which several peaks elute in the range of $6.5-7.1 \mathrm{~min}$. The observed ion at $\mathrm{m} / \mathrm{z} 201.0190$ corresponds to the chemical formula $\mathrm{C}_{8} \mathrm{H}_{9} \mathrm{SO}_{4}^{-}$(error $=15.9 \mathrm{ppm}$ ). Its double bond equivalent (DBE, the number of rings plus double bond) is 4 , which is consistent with an aromatic ring with two methyl groups. Many isomers with xylene or ethyl-benzene backbones and the sulfate directly attached or adjacent to the aromatic ring are possible. Tandem MS analysis of $\mathrm{m} / \mathrm{z} 201$ at $6.98 \mathrm{~min}$ yields product ions at $\mathrm{m} / \mathrm{z}$ 79.9563, 80.9655 and 95.9504 , which are assigned as $\mathrm{SO}_{3}^{-}, \mathrm{HSO}_{3}^{-}$and $\mathrm{SO}_{4}^{--}$(errors: 6.3, 11.1 , and $13.5 \mathrm{ppm}$, respectively). Because of the dominant sulfate radical signal, it is expected that the sulfate moiety is primarily in the benzyl position (i.e. next to but not directly attached to the aromatic ring), as shown in the right inset of Fig. 3b.

The Fig. $3 \mathrm{c}$ inset shows the EIC of $\mathrm{m} / z, 215.04 \pm 0.01$. A cluster of unresolved peaks were eluted in the range of 7.50$8.40 \mathrm{~min}$. The ion observed at $\mathrm{m} / \mathrm{z} 215.0393$ corresponds to the chemical formula $\mathrm{C}_{9} \mathrm{H}_{11} \mathrm{SO}_{4}^{-}$(with an error of $6.9 \mathrm{ppm}$ and DBE of 4). With this chemical formula, many aromatic organosulfate isomers can be predicted that have trimethyl benzene backbones with sulfate attached to side chain or to the aromatic ring. Fragmentation analysis of $m / z, 215$ results in product ions at $m / z$ 95.9505, which is assigned as $\mathrm{SO}_{4}^{--}$ (error $12.9 \mathrm{ppm}$ ), suggesting that the sulfate moiety is attached to the side chain instead of aromatic ring.

The three organosulfates with molecular formulas $\mathrm{C}_{7} \mathrm{H}_{7} \mathrm{SO}_{4}^{-}$( $m / z$ 187), $\mathrm{C}_{8} \mathrm{H}_{9} \mathrm{SO}_{4}^{-}\left(\mathrm{m} / z\right.$ 201), and $\mathrm{C}_{9} \mathrm{H}_{11} \mathrm{SO}_{4}^{-}$ $(\mathrm{m} / \mathrm{z}, 215)$ form a homologous series with increasing number of methylene groups $\left(\mathrm{CH}_{2}, 14 \mathrm{Da}\right)$. The order of elution from the UPLC column supports this observation; increasing hydrophobic characteristic of a molecule increases its retention on the reversed-phase column. As shown in the EIC in Fig. 3, homologs with increasing number of methyl groups are retained longer, with $\mathrm{m} / \mathrm{z} 187$ eluting at 5.77 (benzyl sulfate) and $6.29 \mathrm{~min}$, followed by $\mathrm{m} / \mathrm{z} 201$ at $6.50-7.10 \mathrm{~min}, \mathrm{~m} / \mathrm{z} 215$ at $7.50-8.40 \mathrm{~min}$. The homologous series of organosulfates is analogous to the homologous series of aromatic VOC toluene, xylene, trimethylbenzene - in ambient atmospheres.

\subsection{Potential sources of benzyl sulfate}

Correlation analysis was used to evaluate the co-variation of benzyl sulfate with $\mathrm{PM}_{2.5}$, temperature, combustion tracers, secondary inorganic ions, and SOA tracers in efforts to 
evaluate the potential sources and formation processes of benzyl sulfate. These correlation analyses draw upon prior measurements reported elsewhere (Stone et al., 2010; Shafer et al., 2010) and new measurements made in this study. Statistical analyses were limited to 13 monthly-average benzyl sulfate measurements, and other data with higher time resolution were averaged accordingly.

There was a strong correlation of benzyl sulfate with $\mathrm{PM}_{2.5}$ mass $\left(r^{2}=0.92\right)$, with maximum concentrations occurring in the dry winter and minimum concentrations observed during the monsoon season. $\mathrm{PM}_{2.5}$ loadings in Lahore, located in a subtropical region, are largely driven by primary sources and ambient PM levels vary strongly with season (Stone et al., 2010) as described in Sect. 3.4. Due to the ionic nature of benzyl sulfate, it is expected to be non-volatile at ambient temperatures. An anti-correlation $\left(r^{2}=-0.65\right)$ was observed between benzyl sulfate and temperature, which was consistent with the anti-correlation between $\mathrm{PM}_{2.5}$ mass and temperature $\left(r^{2}=-0.44\right)$, indicative of seasonal trends in PM loadings in Lahore.

A prior source apportionment study of $\mathrm{PM}_{2.5}$ organic carbon in Lahore pointed out the important role of primary combustion sources, including non-catalyzed motor vehicles, biomass burning, local combustion in $\mathrm{PM}_{2.5}$ OC concentrations, and a relatively minor role of SOA (Stone et al., 2010). Tight correlations were observed between benzyl sulfate and EC $\left(r^{2}=0.95\right)$, which is considered as a general tracer for combustion (Schauer, 2003) and levoglucosan $\left(r^{2}=0.82\right)$, which is a tracer of biomass combustion (Simoneit, 1999). The prevalence of primary sources in Lahore and the strength of these correlations suggest that benzyl sulfate may be emitted directly from combustion sources or produced from postemission processing of smoke layers.

Correlations have been reported in marine aerosols between organosulfates and $\mathrm{SO}_{4}^{2-}\left(r^{2}=0.72\right)$ (Hawkins et al., 2010), and are consistent with the laboratory observation that sulfate is a precursor to organosulfate formation (Surratt et al., 2007). However, benzyl sulfate and sulfate showed only a weak correlation in this study $\left(r^{2}=0.35\right)$. A stronger correlation was observed between benzyl sulfate and nitrate $\left(r^{2}=0.92\right)$, suggesting that aromatic organosulfates concentrations may be enhanced by acidity provided by $\mathrm{HNO}_{3}$ or chemical reactions initiated by $\mathrm{NO}_{\mathrm{x}}$ (Hatch et al., 2011). For example, $\mathrm{HNO}_{3}$ has been observed to react with atmospherically relevant hydroxy epoxides in the bulk aqueous phase to form organonitrates, which subsequently converted quickly to organosulfates due to their reactions with sulfate (Darer et al., 2011). Organonitrates, which may be precursors to benzyl sulfate, are semi-volatile with enhanced partitioning to the aerosol phase expected during cooler months. The stronger correlations with nitrate could also be related with the emission of benzyl sulfate from combustion sources that also emit $\mathrm{NO}_{\mathrm{x}}$, which is a precursor to nitrate.

Secondary reactions are well-established sources of biogenic organosulfates (Liggio and Li, 2006; Iinuma et al.,
2007; Surratt et al., 2008; Chan et al., 2011). Biogenic organosulfates derived from monoterpenes were also evaluated with respect to benzyl sulfate. Three structural isomers of nitroxy organosulfates at $\mathrm{m} / \mathrm{z} 294.0653$ with a chemical formula $\mathrm{C}_{10} \mathrm{H}_{16} \mathrm{NO}_{7} \mathrm{~S}^{-}$have been reported to be generated due to the oxidation of $\alpha$-pinene in the smog chamber (Surratt et al., 2008) and their presence was previously reported in $\mathrm{PM}_{2.5}$ from Lahore (Stone et al., 2012). While not quantified in this study, their signals were evaluated using the HRMS (high-resolution mass spectrometry) signal at retention times 8.8, 9.6 and $9.8 \mathrm{~min}$. The sum of the three major $m / z 294$ signals showed a weak correlation with benzyl sulfate $\left(r^{2}=0.47\right)$, suggesting biogenic organosulfates have different sources and/or formation mechanisms than aromatic organosulfates. Although limited by sample number and monthly time resolution, these correlation studies point towards primary combustion sources as possible origins for aromatic organosulfates and indicate that their atmospheric origins are different from biogenic organosulfates.

\subsection{Potential formation processes of aromatic organosulfates}

As biogenic VOC are established precursors to aliphatic organosulfates, it is reasonable to consider that anthropogenic VOC are precursors to aromatic organosulfates. Anthropogenic VOC comprise up to $40 \%$ of the urban volatile hydrocarbon mixture in various parts of the world (Bloss et al., 2005; Jang and Kamens, 2001), and are particularly abundant in urban areas of Pakistan (Barletta et al., 2002). Of the aromatics, benzene, toluene, xylenes, ethylbenzene, and trimethylbenzene make up $60-75 \%$ of this load, with toluene being the most abundant compound (Jang and Kamens, 2001). Aromatic VOC can be oxidized in the time scale of a few hours to days in the atmosphere to generate epoxides, hydroxy and other functional groups containing low volatility products (Hamilton et al., 2005; Atkinson, 2000; Baltaretu et al., 2009). Smog chamber studies of aromatic VOC have comparable SOA yields when seed particles are either acidic or neutral (Ng et al., 2007), unlike biogenic VOC whose SOA formation is enhanced when acidic seed particles are present (Surratt et al., 2007). More recent chamber experiments have demonstrated the important role of relative humidity in organosulfate formation (Zhang et al., 2011), such that the low relative humidities $(<5 \%)$ in the study of aromatic VOC may have precluded organosulfate formation ( $\mathrm{Ng}$ et al., 2007).

The four established pathways of organosulfate formation in the atmosphere include (a) nucleophilic ring-opening of epoxides with sulfuric acid (Iinuma et al., 2007; Paulot et al., 2009b; Chan et al., 2011; Minerath et al., 2009; Darer et al., 2011), (b) radical initiated reactions (Noziere et al., 2010), (c) substitution reactions of organonitrates (Paulot et al., 2009a; Rollins et al., 2009; Fry et al., 2009), and (d) condensation of alcohols with sulfuric acid (Liggio et al., 2005; 
Minerath et al., 2008). None of these mechanisms provide a clear pathway to the formation of benzyl sulfate, suggesting that other formation processes or sources exist.

In the epoxide pathway, epoxides generated during gasphase photooxidation of alkenes go on to react with sulfuric acid to form hydroxy-organosulfates (Iinuma et al., 2007; Paulot et al., 2009b; Chan et al., 2010; Minerath et al., 2009; Darer et al., 2011). The time scale of this reaction is in the range of minutes to hours (Minerath et al., 2009). However, this pathway cannot explain the formation of benzyl sulfate because it would require that the aromatic ring be broken, yet the ring is intact in benzyl sulfate. Secondly, radical initiated reactions, discussed by Noziere et al. (2010), involve the addition of sulfate radicals and a hydroxyl group to adjacent olefinic carbon atoms. This pathway results in the formation of hydroxy-organosulfates, not the aromatic organosulfates observed in this study. In the third route, organonitrates that are formed by the oxidation of biogenic VOC, mainly under high $\mathrm{NO}_{\mathrm{x}}$ conditions, eliminate the nitrate moiety by substitution with bisulfate to form an organosulfate (Paulot et al., 2009a; Rollins et al., 2009; Fry et al., 2009). Tertiary organonitrates undergo rapid substitution by sulfate on the time scales of minutes, while primary organonitrates remained intact (Darer et al., 2011). The organonitrates pathway is plausible, as benzylnitrate is formed by the oxidation of aromatic VOC (Atkinson and Arey, 2003). These compounds could partition to the aerosol phase and further react with sulfuric acid to produce benzyl sulfate. Although the reactivity of some primary nitrates is reportedly slow (Darer et al., 2011), reactivity of benzyl nitrate has not yet been studied. Finally, in the condensation pathway, benzyl alcohol reacts with sulfuric acid to form benzyl sulfate; however, alcohol sulfate esterification reactions have been shown to be kinetically infeasible under typical atmospheric conditions for a number of alcohols (Minerath et al., 2008).

\subsection{Matrix effects on the quantitation of benzyl sulfate}

Aerosol samples are a complex mixture, in which other aerosol components may interfere with analytical measurement of benzyl sulfate. The combined effect of all components of the sample other than the analyte on the measurement of the quantity is defined as matrix effects. A sample matrix may affect analyte quantitation by introducing ion suppression or enhancement in ESI MS by altering the ionization efficiency or electrospray droplet formation (Van Eeckhaut et al., 2009). Matrix effects can be addressed using a variety of methods, including (1) modification of mass spectrometric conditions, (2) pre-treatment and extraction process of samples, (3) modification of chromatographic conditions, and (4) selection of the calibration strategy (Gosetti et al., 2010).

In this study, matrix effects were evaluated by comparing external calibration to the method of standard addition. Theoretically, the external calibration is prone to matrix effects

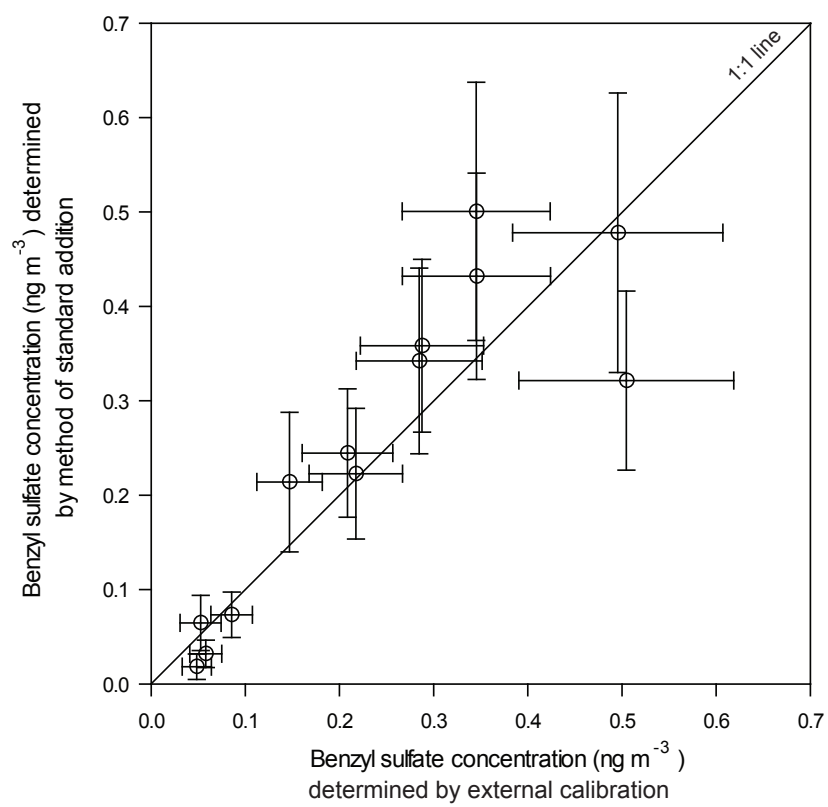

Fig. 4. Comparison of concentrations of benzyl sulfate in $\mathrm{PM}_{2.5}$ determined by UPLC TQ MS by the methods of external calibration and standard addition. Error bars represent the analytical uncertainty.

because the analyte concentration in a complex matrix is determined using a standard prepared in absence of the matrix. The method of standard addition effectively generates a calibration curve within the sample matrix, thus nullifying matrix effects (Gosetti et al., 2010). Figure 4 shows the comparison of the concentrations of benzyl sulfate in atmospheric aerosols between external and standard addition calibration methods. All the data points, except one outlier, are near to $1: 1$ line. The slope of the line was found by linear regression and had a relation of $\mathrm{y}=1.03 \mathrm{x}\left(r^{2}=0.76\right)$. This $3 \%$ bias from the $1: 1$ line is less than the analytical measurement uncertainty and thus matrix effects were considered negligible in quantitation of benzyl sulfate. The absence of matrix effects can be attributed to the good separation of benzyl sulfate from the inorganic matrix, which eluted more than $5 \mathrm{~min}$ prior to benzyl sulfate. Additionally, the use of MRM mode for data acquiring in the TQ MS provides two levels of mass filtering and monitoring, reducing the potential for competing ions (Domon and Aebersold, 2006).

\section{Conclusions}

This study presents the identification and quantification of aromatic organosulfates in atmospheric aerosols for the first time. In $\mathrm{PM}_{2.5}$ in the megacity Lahore, Pakistan, other aromatic organosulfates were observed whose chemical structures reflect aromatic VOC precursors such as toluene, $x y-$ lene, and trimethylbenzene, suggestive of secondary origins. 
These aromatic VOC are ubiquitous in urban environments and are emitted by vehicles and fuel evaporation/spillage during storage and transportation (Atkinson, 2000). However, the established mechanisms of organosulfate formation do not present a clear pathway to aromatic organosulfate formation. More tight correlations of benzyl sulfate with combustion tracers (EC and levoglucosan) than with secondary tracers $\left(\mathrm{SO}_{4}^{2-}\right.$ and $\alpha$-pinene derived nitrooxy organosulfates) suggest that aromatic organosulfates may be related to combustion emissions.

Although aromatic organosulfates were observed at low concentrations, they may be useful atmospheric tracers because of their atmospheric stability (Darer et al., 2011), presence in the particle phase, and very low detection limits. In particular, tracers of SOA are also needed to accurately quantify the relative contributions of biogenic and anthropogenic SOA in ambient atmospheres (Kleindienst et al., 2010), which are currently subject to major uncertainties (Hallquist et al., 2009). Further studies are required for understanding the utility of aromatic organosulfates as tracers of atmospheric aerosol processes and sources.

\section{Supplementary material related to this article is available online at: http://www.atmos-chem-phys.net/13/ 4865/2013/acp-13-4865-2013-supplement.pdf.}

Acknowledgements. Funding for sample collection was provided courtesy of Government of Pakistan, the Pakistan Higher Education Commission and the United States Agency for International Development (USAID). We are thankful to James Schauer for filter samples. We also thank Lynn Teesch and Vic Parcell at the University of Iowa High Resolution Mass Spectrometry for assistance with data acquisition. The funding for chemical analysis portion of this research was provided by the University of Iowa. Frank Keutsch, Ge Yu, and Catalina Suarez thank the National Science Foundation for funding (grant \# AGS-1051338).

Edited by: J. Liggio

\section{References}

Altieri, K. E., Turpin, B. J., and Seitzinger, S. P.: Composition of Dissolved Organic Nitrogen in Continental Precipitation Investigated by Ultra-High Resolution FT-ICR Mass Spectrometry, Environ. Sci. Technol., 43, 6950-6955, doi:10.1021/es9007849, 2009.

Atkinson, R.: Atmospheric chemistry of VOCs and $\mathrm{NO}_{\mathrm{x}}$, Atmos. Environ., 34, 2063-2101, doi:10.1016/s1352-2310(99)00460-4, 2000.

Atkinson, R. and Arey, J.: Atmospheric degradation of volatile organic compounds, Chem Rev, 103, 4605-4638, doi:10.1021/Cr0206420, 2003.

Attygalle, A. B., Garcia-Rubio, S., Ta, J., and Meinwald, J.: Collisionally-induced dissociation mass spectra of organic sulfate anions, J. Chem. Soc. Perk. T., 2, 498-506, doi:10.1039/B009019k, 2001.
Baltaretu, C. O., Lichtman, E. I., Hadler, A. B., and Elrod, M. J.: Primary Atmospheric Oxidation Mechanism for Toluene, J. Phys. Chem. A, 113, 221-230, doi:10.1021/Jp806841t, 2009.

Barletta, B., Meinardi, S., Simpson, I. J., Khwaja, H. A., Blake, D. R., and Rowland, F. S.: Mixing ratios of volatile organic compounds (VOCs) in the atmosphere of Karachi, Pakistan, Atmos. Environ., 36, 3429-3443, doi:10.1016/s1352-2310(02)00302-3, 2002.

Bloss, C., Wagner, V., Jenkin, M. E., Volkamer, R., Bloss, W. J., Lee, J. D., Heard, D. E., Wirtz, K., Martin-Reviejo, M., Rea, G., Wenger, J. C., and Pilling, M. J.: Development of a detailed chemical mechanism (MCMv3.1) for the atmospheric oxidation of aromatic hydrocarbons, Atmos. Chem. Phys., 5, 641-664, doi:10.5194/acp-5-641-2005, 2005.

Chan, M. N., Surratt, J. D., Claeys, M., Edgerton, E. S., Tanner, R. L., Shaw, S. L., Zheng, M., Knipping, E. M., Eddingsaas, N. C., Wennberg, P. O., and Seinfeld, J. H.: Characterization and Quantification of Isoprene-Derived Epoxydiols in Ambient Aerosol in the Southeastern United States, Environ. Sci. Technol., 44, 4590 4596, doi:10.1021/Es100596b, 2010.

Chan, M. N., Surratt, J. D., Chan, A. W. H., Schilling, K., Offenberg, J. H., Lewandowski, M., Edney, E. O., Kleindienst, T. E., Jaoui, M., Edgerton, E. S., Tanner, R. L., Shaw, S. L., Zheng, M., Knipping, E. M., and Seinfeld, J. H.: Influence of aerosol acidity on the chemical composition of secondary organic aerosol from $\beta$-caryophyllene, Atmos. Chem. Phys., 11, 1735-1751, doi:105194/acp-11-1735-2011, 2011.

Darer, A. I., Cole-Filipiak, N. C., O'Connor, A. E., and Elrod, M. J.: Formation and Stability of Atmospherically Relevant IsopreneDerived Organosulfates and Organonitrates, Environ. Sci. Technol., 45, 1895-1902, doi:10.1021/Es103797z, 2011.

Davidson, C. I., Phalen, R. F., and Solomon, P. A.: Airborne Particulate Matter and Human Health: A Review, Aerosol Sci. Technol., 39, 737-749, doi:10.1080/02786820500191348, 2005.

Domon, B. and Aebersold, R.: Mass Spectrometry and Protein Analysis, Science, 312, 212-217, doi:10.1126/science.1124619, 2006.

Ervens, B., Feingold, G., and Kreidenweis, S. M.: Influence of water-soluble organic carbon on cloud drop number concentration, J. Geophys. Res., 110, D18211, doi:10.1029/2004JD005634, 2005.

Fine, P. M., Chakrabarti, B., Krudysz, M., Schauer, J. J., and Sioutas, C.: Diurnal variations of individual organic compound constituents of ultrafine and accumulation mode particulate matter in the Los Angeles basin, Environ. Sci. Technol., 38, 12961304, doi:10.1021/Es0348389, 2004.

Froyd, K. D., Murphy, S. M., Murphy, D. M., de Gouw, J. A., Eddingsaas, N. C., and Wennberg, P. O.: Contribution of isoprene-derived organosulfates to free tropospheric aerosol mass, P. Natl. Acad. Sci. USA, 107, 21360-21365, doi:10.1073/pnas.1012561107, 2010.

Fry, J. L., Kiendler-Scharr, A., Rollins, A. W., Wooldridge, P. J., Brown, S. S., Fuchs, H., Dubé, W., Mensah, A., dal Maso, M., Tillmann, R., Dorn, H.-P., Brauers, T., and Cohen, R. C.: Organic nitrate and secondary organic aerosol yield from $\mathrm{NO}_{3}$ oxidation of $\beta$-pinene evaluated using a gas-phase kinetics/aerosol partitioning model, Atmos. Chem. Phys., 9, 14311449, doi:10.5194/acp-9-1431-2009, 2009. 
Fuzzi, S., Andreae, M. O., Huebert, B. J., Kulmala, M., Bond, T. C., Boy, M., Doherty, S. J., Guenther, A., Kanakidou, M., Kawamura, K., Kerminen, V.-M., Lohmann, U., Russell, L. M., and Pöschl, U.: Critical assessment of the current state of scientific knowledge, terminology, and research needs concerning the role of organic aerosols in the atmosphere, climate, and global change, Atmos. Chem. Phys., 6, 2017-2038, doi:10.5194/acp-62017-2006, 2006.

Galloway, M. M., Chhabra, P. S., Chan, A. W. H., Surratt, J. D., Flagan, R. C., Seinfeld, J. H., and Keutsch, F. N.: Glyoxal uptake on ammonium sulphate seed aerosol: reaction products and reversibility of uptake under dark and irradiated conditions, Atmos. Chem. Phys., 9, 3331-3345, doi:10.5194/acp-9-3331-2009, 2009.

Goldstein, A. H. and Galbally, I. E.: Known and unexplained organic constituents in the earth's atmosphere, Environ. Sci. Technol., 41, 1514-1521, 2007.

Gosetti, F., Mazzucco, E., Zampieri, D., and Gennaro, M. C.: Signal suppression/enhancement in high-performance liquid chromatography tandem mass spectrometry, J Chromatogr A, 1217, 3929-3937, doi:10.1016/j.chroma.2009.11.060, 2010.

Hallquist, M., Wenger, J. C., Baltensperger, U., Rudich, Y., Simpson, D., Claeys, M., Dommen, J., Donahue, N. M., George, C., Goldstein, A. H., Hamilton, J. F., Herrmann, H., Hoffmann, T., Iinuma, Y., Jang, M., Jenkin, M. E., Jimenez, J. L., KiendlerScharr, A., Maenhaut, W., McFiggans, G., Mentel, T. F., Monod, A., Prévôt, A. S. H., Seinfeld, J. H., Surratt, J. D., Szmigielski, R., and Wildt, J.: The formation, properties and impact of secondary organic aerosol: current and emerging issues, Atmos. Chem. Phys., 9, 5155-5236, doi:10.5194/acp-9-5155-2009, 2009.

Hamilton, J. F., Webb, P. J., Lewis, A. C., and Reviejo, M. M.: Quantifying small molecules in secondary organic aerosol formed during the photo-oxidation of toluene with hydroxyl radicals, Atmos. Environ., 39, 7263-7275, doi:10.1016/j.atmosenv.2005.09.006, 2005.

Hatch, L. E., Creamean, J. M., Ault, A. P., Surratt, J. D., Chan, M. N., Seinfeld, J. H., Edgerton, E. S., Su, Y. X., and Prather, K. A.: Measurements of Isoprene-Derived Organosulfates in Ambient Aerosols by Aerosol Time-of-Flight Mass Spectrometry-Part 2: Temporal Variability and Formation Mechanisms, Environ. Sci. Technol., 45, 8648-8655, doi:10.1021/Es2011836, 2011.

Hawkins, L. N., Russell, L. M., Covert, D. S., Quinn, P. K., and Bates, T. S.: Carboxylic acids, sulfates, and organosulfates in processed continental organic aerosol over the southeast Pacific Ocean during VOCALS-REx 2008, J. Geophys. Res., 115, D13201, doi:10.1029/2009jd013276, 2010.

Iinuma, Y., Muller, C., Berndt, T., Böge, O., Claeys, M., and Herrmann, H.: Evidence for the existence of organosulfates from $\beta$-pinene ozonolysis in ambient secondary organic aerosol, Environ. Sci. Technol., 41, 6678-6683, doi:10.1021/Es070938t, 2007.

Jang, M. and Kamens, R. M.: Characterization of Secondary Aerosol from the Photooxidation of Toluene in the Presence of $\mathrm{NO}_{\mathrm{x}}$ and 1-Propene, Environ. Sci. Technol., 35, 3626-3639, doi:10.1021/es010676+, 2001.

Kanakidou, M., Seinfeld, J. H., Pandis, S. N., Barnes, I., Dentener, F. J., Facchini, M. C., Van Dingenen, R., Ervens, B., Nenes, A., Nielsen, C. J., Swietlicki, E., Putaud, J. P., Balkanski, Y., Fuzzi,
S., Horth, J., Moortgat, G. K., Winterhalter, R., Myhre, C. E. L., Tsigaridis, K., Vignati, E., Stephanou, E. G., and Wilson, J.: Organic aerosol and global climate modelling: a review, Atmos. Chem. Phys., 5, 1053-1123, doi:10.5194/acp-5-1053-2005, 2005.

Kleindienst, T. E., Lewandowski, M., Offenberg, J. H., Edney, E. O., Jaoui, M., Zheng, M., Ding, X. A., and Edgerton, E. S.: Contribution of Primary and Secondary Sources to Organic Aerosol and $\mathrm{PM}_{2.5}$ at SEARCH Network Sites, J. Air Waste Manage., 60, 1388-1399, doi:10.3155/1047-3289.60.11.1388, 2010.

Kundu, S., Kawamura, K., and Lee, M.: Seasonal variations of diacids, ketoacids, and $\alpha$-dicarbonyls in aerosols at Gosan, Jeju Island, South Korea: Implications for sources, formation, and degradation during long-range transport, 115, D19307, doi:10.1029/2010JD013973, 2010.

Liggio, J. and Li, S. M.: Organosulfate formation during the uptake of pinonaldehyde on acidic sulfate aerosols, Geophys Res Lett, 33, L13808, doi:10.1029/2006g1026079, 2006.

Liggio, J., Li, S. M., and Mclaren, R.: Heterogeneous reactions of glyoxal on particulate matter: Identification of acetals and sulfate esters, Environ. Sci. Technol., 39, 1532-1541, doi:10.1021/Es048375y, 2005.

Lukács, H., Gelencsér, A., Hoffer, A., Kiss, G., Horváth, K., and Hartyáni, Z.: Quantitative assessment of organosulfates in sizesegregated rural fine aerosol, Atmos. Chem. Phys., 9, 231-238, doi:10.5194/acp-9-231-2009, 2009.

Mahowald, N.: Aerosol Indirect Effect on Biogeochemical Cycles and Climate, Science, 334, 794-796, doi:101126/science.1207374, 2011.

Mazzoleni, L. R., Ehrmann, B. M., Shen, X., Marshall, A. G., and Collett, J. L.: Water-Soluble Atmospheric Organic Matter in Fog: Exact Masses and Chemical Formula Identification by Ultrahigh-Resolution Fourier Transform Ion Cyclotron Resonance Mass Spectrometry, Environ. Sci. Technol., 44, 36903697, doi:10.1021/es903409k, 2010.

Mccormic, R. A. and Ludwig, J. H.: Climate Modification by Atmospheric Aerosols, Science, 156, 1358-1359, 1967.

Minerath, E. C., Casale, M. T., and Elrod, M. J.: Kinetics feasibility study of alcohol sulfate esterification reactions in tropospheric aerosols, Environ. Sci. Technol., 42, 4410-4415, doi:10.1021/Es8004333, 2008.

Minerath, E. C., Schultz, M. P., and Elrod, M. J.: Kinetics of the Reactions of Isoprene-Derived Epoxides in Model Tropospheric Aerosol Solutions, Environ. Sci. Technol., 43, 81338139, doi:10.1021/Es902304p, 2009.

Ng, N. L., Kroll, J. H., Chan, A. W. H., Chhabra, P. S., Flagan, R. C., and Seinfeld, J. H.: Secondary organic aerosol formation from m-xylene, toluene, and benzene, Atmos. Chem. Phys., 7, 3909-3922, doi:10.5194/acp-7-3909-2007, 2007.

Nguyen, T. B., Lee, P. B., Updyke, K. M., Bones, D. L., Laskin, J., Laskin, A., and Nizkorodov, S. A.: Formation of nitrogenand sulfur-containing light-absorbing compounds accelerated by evaporation of water from secondary organic aerosols, J. Geophys. Res.-Atmos., 117, D01207, doi:10.1029/2011jd016944, 2012.

Noziere, B., Ekstrom, S., Alsberg, T., and Holmstrom, S.: Radical-initiated formation of organosulfates and surfactants in atmospheric aerosols, Geophys Res Lett, 37, L05806, doi:10.1029/2009g1041683, 2010. 
Olson, C. N., Galloway, M. M., Yu, G., Hedman, C. J., Lockett, M. R., Yoon, T., Stone, E. A., Smith, L. M., and Keutsch, F. N.: Hydroxycarboxylic Acid-Derived Organosulfates: Synthesis, Stability, and Quantification in Ambient Aerosol, Environ. Sci. Technol., 45, 6468-6474, doi:10.1021/Es201039p, 2011.

Paulot, F., Crounse, J. D., Kjaergaard, H. G., Kroll, J. H., Seinfeld, J. H., and Wennberg, P. O.: Isoprene photooxidation: new insights into the production of acids and organic nitrates, Atmos. Chem. Phys., 9, 1479-1501, doi:10.5194/acp-9-1479-2009, 2009a.

Paulot, F., Crounse, J. D., Kjaergaard, H. G., Kurten, A., St Clair, J. M., Seinfeld, J. H., and Wennberg, P. O.: Unexpected Epoxide Formation in the Gas-Phase Photooxidation of Isoprene, Science, 325, 730-733, doi:101126/science.1172910, 2009b

Perri, M. J., Lim, Y. B., Seitzinger, S. P., and Turpin, B. J.: Organosulfates from glycolaldehyde in aqueous aerosols and clouds: Laboratory studies, Atmos. Environ., 44, 2658-2664, 2010.

Pope, C. A., Burnett, R. T., Thun, M. J., Calle, E. E., Krewski, D., Ito, K., and Thurston, G. D.: Lung cancer, cardiopulmonary mortality, and long-term exposure to fine particulate air pollution, J. Am. Med. Assoc., 287, 1132-1141, 2002.

Ramanathan, V., Crutzen, P. J., Lelieveld, J., Mitra, A. P., Althausen, D., Anderson, J., Andreae, M. O., Cantrell, W., Cass, G. R., Chung, C. E., Clarke, A. D., Coakley, J. A., Collins, W. D., Conant, W. C., Dulac, F., Heintzenberg, J., Heymsfield, A. J., Holben, B., Howell, S., Hudson, J., Jayaraman, A., Kiehl, J. T., Krishnamurti, T. N., Lubin, D., McFarquhar, G., Novakov, T., Ogren, J. A., Podgorny, I. A., Prather, K., Priestley, K., Prospero, J. M., Quinn, P. K., Rajeev, K., Rasch, P., Rupert, S., Sadourny, R., Satheesh, S. K., Shaw, G. E., Sheridan, P., and Valero, F. P. J.: Indian Ocean Experiment: An integrated analysis of the climate forcing and effects of the great Indo-Asian haze, J. Geophys. Res.-Atmos., 106, 28371-28398, 2001.

Riipinen, I., Yli-Juuti, T., Pierce, J. R., Petaja, T., Worsnop, D. R., Kulmala, M., and Donahue, N. M.: The contribution of organics to atmospheric nanoparticle growth, Nature Geosci., 5, 453-458, 2012

Roberts, G. C., Nenes, A., Seinfeld, J. H., and Andreae, M. O.: Impact of biomass burning on cloud properties in the Amazon Basin, J. Geophys. Res.-Atmos., 108, 4062, doi:10.1029/2001jd000985, 2003.

Rollins, A. W., Fry, J. L., Kiendler-Scharr, A., Wooldridge, P. J., Brown, S. S., Fuchs, H., Dube, W. P., Mensah, A., Tillmann, R., Dorn, H. P., Brauers, T., and Cohen, R. C.: Isoprene oxidation by nitrate radical: Alkyl nitrate and secondary organic aerosol yields, Abstr. Pap. Am. Chem. S., 237, p. 288, 2009.

Romero, F., and Oehme, M.: Organosulfates - A new component of humic-like substances in atmospheric aerosols?, J. Atmos. Chem., 52, 283-294, doi:10.1007/s 10874-005-0594-y, 2005.

Saxena, P. and Hildemann, L. M.: Water-soluble organics in atmospheric particles: A critical review of the literature and application of thermodynamics to identify candidate compounds, J. Atmos. Chem., 24, 57-109, 1996.

Schauer, J. J.: Evaluation of elemental carbon as a marker for diesel particulate matter, J. Expo. Anal. Environ. Epid., 13, 443-453, doi:10.1038/sj.jea.7500298, 2003.

Schmitt-Kopplin, P., Gelencsér, A., Dabek-Zlotorzynska, E., Kiss, G., Hertkorn, N., Harir, M., Hong, Y., and Gebefügi, I.: Analysis of the Unresolved Organic Fraction in Atmospheric
Aerosols with Ultrahigh-Resolution Mass Spectrometry and Nuclear Magnetic Resonance Spectroscopy: Organosulfates As Photochemical Smog Constituents, Anal. Chem., 82, 8017-8026, doi:10.1021/ac101444r, 2010.

Shafer, M. M., Perkins, D. A., Antkiewicz, D. S., Stone, E. A., Quraishi, T. A., and Schauer, J. J.: Reactive oxygen species activity and chemical speciation of size-fractionated atmospheric particulate matter from Lahore, Pakistan: an important role for transition metals, J. Environ. Monitor., 12, 704-715, doi:10.1039/B915008k, 2010.

Shapiro, E. L., Szprengiel, J., Sareen, N., Jen, C. N., Giordano, M. R., and McNeill, V. F.: Light-absorbing secondary organic material formed by glyoxal in aqueous aerosol mimics, Atmos. Chem. Phys., 9, 2289-2300, doi:10.5194/acp-9-2289-2009, 2009.

Simoneit, B. R. T.: A review of biomarker compounds as source indicators and tracers for air pollution, Environ. Sci. Pollut. R., 6, 159-169, doi:10.1007/Bf02987621, 1999.

Stone, E., Schauer, J., Quraishi, T. A., and Mahmood, A.: Chemical characterization and source apportionment of fine and coarse particulate matter in Lahore, Pakistan, Atmos. Environ., 44, 10621070, doi:10.1016/j.atmosenv.2009.12.015, 2010.

Stone, E. A., Hedman, C. J., Sheesley, R. J., Shafer, M. M., and Schauer, J. J.: Investigating the chemical nature of humic-like substances (HULIS) in North American atmospheric aerosols by liquid chromatography tandem mass spectrometry, Atmos. Environ., 43, 4205-4213, doi:10.1016/j.atmosenv.2009.05.030, 2009.

Stone, E. A., Yang, L. M., Yu, L. Y. E., and Rupakheti, M.: Characterization of organosulfates in atmospheric aerosols at Four Asian locations, Atmos. Environ., 47, 323-329, doi:10.1016/j.atmosenv.2011.10.058, 2012.

Surratt, J. D., Kroll, J. H., Kleindienst, T. E., Edney, E. O., Claeys, M., Sorooshian, A., Ng, N. L., Offenberg, J. H., Lewandowski, M., Jaoui, M., Flagan, R. C., and Seinfeld, J. H.: Evidence for organosulfates in secondary organic aerosol, Environ. Sci. Technol., 41, 517-527, doi:10.1021/Es062081q, 2007.

Surratt, J. D., Gomez-Gonzalez, Y., Chan, A. W. H., Vermeylen, R., Shahgholi, M., Kleindienst, T. E., Edney, E. O., Offenberg, J. H., Lewandowski, M., Jaoui, M., Maenhaut, W., Claeys, M., Flagan, R. C., and Seinfeld, J. H.: Organosulfate formation in biogenic secondary organic aerosol, J. Phys. Chem. A, 112, 8345-8378, doi:10.1021/Jp802310p, 2008.

Tolocka, M. P. and Turpin, B.: Contribution of Organosulfur Compounds to Organic Aerosol Mass, Environ. Sci. Technol., 46, 7978-7983, doi:10.1021/Es300651v, 2012.

Twomey, S.: Pollution and the planetary albedo, Atmos. Environ., 8, 1251-1256, doi:10.1016/0004-6981(74)90004-3, 1974.

Van Eeckhaut, A., Lanckmans, K., Sarre, S., Smolders, I., and Michotte, Y.: Validation of bioanalytical LC-MS/MS assays: Evaluation of matrix effects, J. Chromatogr. B, 877, 2198-2207, doi:10.1016/j.jchromb.2009.01.003, 2009.

von Schneidemesser, E., Stone, E. A., Quraishi, T. A., Shafer, M. M., and Schauer, J. J.: Toxic metals in the atmosphere in Lahore, Pakistan, Sci. Total Environ., 408, 1640-1648, doi:10.1016/j.scitotenv.2009.12.022, 2010.

Zhang, H., Surratt, J. D., Lin, Y. H., Bapat, J., and Kamens, R. M.: Effect of relative humidity on SOA formation from isoprene/NO photooxidation: enhancement of 2-methylglyceric acid and its corresponding oligoesters under dry conditions, Atmos. Chem. Phys., 11, 6411-6424, doi:10.5194/acp-11-6411-2011, 2011. 